\title{
Habitat selection by, and carrying capacity for, the Critically Endangered black-faced lion tamarin Leontopithecus caissara (Primates: Callitrichidae)
}

\author{
Alexandre T. Amaral Nascimento and Lucia A.J.Schmidi in
}

\begin{abstract}
The Critically Endangered black-faced lion tamarin Leontopithecus caissara has a restricted distribution consisting of small mainland and island populations each with distinct habitats in coastal south-eastern Brazil. The conservation action plan for the species recommends translocation to increase population size and promote genetic exchange among threatened isolated populations, measures that require an understanding of habitat and resource requirements. We investigated habitat selection by the black-faced lion tamarin, comparing habitats and examining frequency of use by two insular groups and two mainland groups. Using this understanding of habitat preferences we were able to refine current estimates of the carrying capacity $(K)$ for this species. Habitats preferred by mainland groups were swamps and inundated areas and secondary forest. Submontane forest was avoided, as were hydromorphic lowland forest and urbanized areas. Island groups used mainly tall lowland forest and arboreal restinga (forest on sandy soil). The finding that $L$. caissara avoids montane forest sheds light on its restricted distribution to low elevation coastal plains. An estimate of $K$ indicated c. 700 individuals, which could be increased to $c$. 1,500 with appropriate conservation management measures. Findings agree with the supposition that lion tamarins are typical of mature Atlantic forest, with little altitudinal variation but flexible in their use of successional stages. Future conservation management measures should account for differences in habitat use, selection and differences between island and mainland habitats.
\end{abstract}

Keywords Atlantic forest, black-faced lion tamarin, Brazil, Callitrichidae, carrying capacity, habitat preference, Leontopithecus caissara, Primates

\section{Introduction}

The black-faced lion tamarin Leontopithecus caissara (Lorini \& Persson, 1990) occurs in the coastal Atlantic forest of the south-east of São Paulo and north-east of

Alexandre T. Amaral Nascimento (Corresponding author) and Lucia A.J. Schmidlin Instituto de Pesquisas Ecológicas, Caixa Postal 47, Cep 12960-000, Nazaré Paulista, São Paulo, Brazil. E-mail alexandre@ipe.org.br

Received 9 November 2009. Revision requested 8 February 2010.

Accepted 6 April 2010.
Paraná states in Brazil (Lorini \& Persson, 1994; Prado et al., 2003). It is categorized as Critically Endangered on the IUCN Red List (IUCN, 2009) because of its small population at c. 400 individuals (Amaral et al., 2003) and a geographical distribution of $<300 \mathrm{~km}^{2}$ (Lorini \& Persson, 1994; Prado et al., 2003; Schmidlin, 2004; Fig. 1). There are several small populations on the mainland and a population on the island of Superagui (originally a peninsula but isolated by the construction of a canal in 1953; Vivekananda, 2001). Efforts to promote the survival of the species and its habitat have resulted in a long-term conservation programme that combines research and conservation management (Holst et al., 2006). Key to the success of any conservation measures for this species is a good understanding of its use of different habitats (Garshelis, 2000; Matthiopoulos, 2003; Valladares-Padua et al., 2003; Rhodes et al., 2005). We therefore investigated habitat selection by L. caissara, comparing habitat use by two groups on the island and two on the mainland.

Habitat selection is manifested by the non-random use of available vegetation types, with some used relatively more than others or for different purposes, or some used exclusively (Fretwell \& Lucas, 1970; Holt, 1985; Pulliam, 1988; Morris, 2003). We investigated the relationship between use of space and the availability of vegetation types within the home ranges of four groups of L. caissara.

With an understanding of habitat preference we were then able to refine current estimates of the carrying capacity $(K)$ for the species. Previous predictions of $K$ were based on habitat use by the island population (Holst et al., 2006) and, for the first time, we have been able to produce estimates for the mainland (Schmidlin, 2004). These estimates of $K$ indicate the maximum number of lion tamarins that could be supported by the forests on the island and mainland: vital information for the conservation management of the species and the promotion of its long-term survival.

\section{Study area}

The ranging behaviour of $L$. caissara was studied in the northernmost and southernmost of its known geographical distribution (Fig. 1): two groups in the vicinity of Ariri in the north of São Paulo state and two in the south of Superagui island in the state of Paraná. Following the classification of Köppen, the climate of the region is Cfa: humid, mesothermic subtropical. The coldest months 


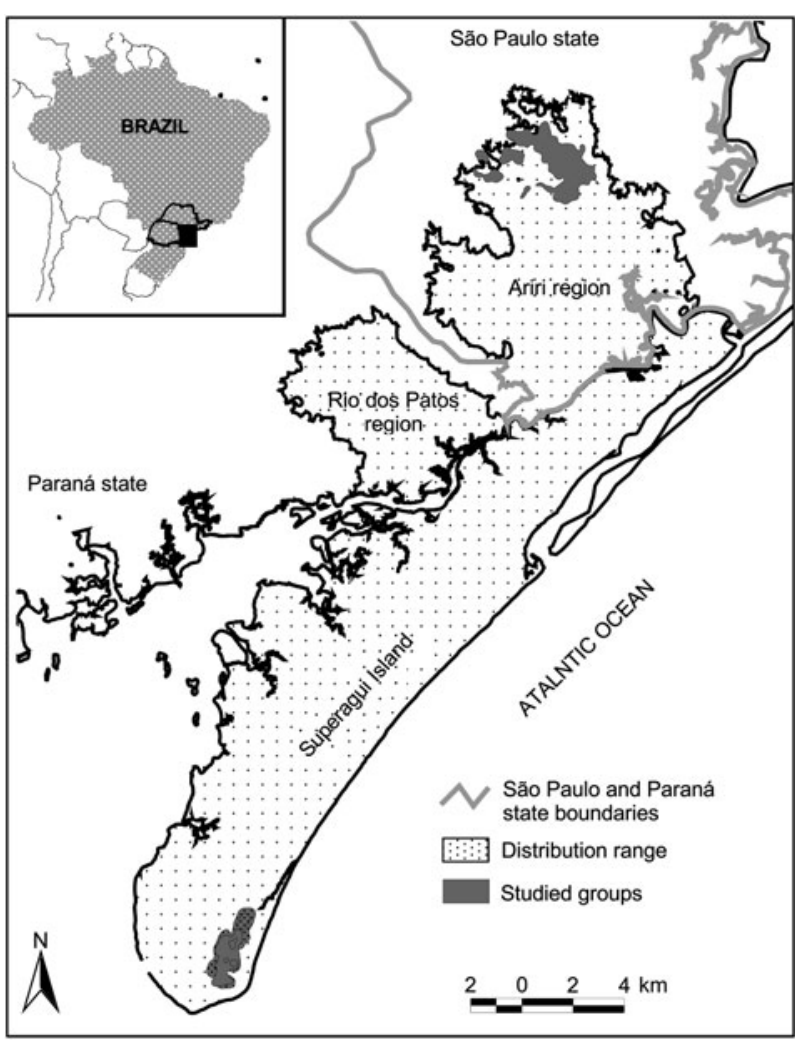

FIG. 1 Location of the four studied groups of Leontopithecus caissara at Ariri and on the island of Superagui, Brazil. The shaded rectangle on the inset indicates the location of the main figure in Brazil.

(May-October) average $<18^{\circ} \mathrm{C}$ and the warmest months (November-April) average $>22^{\circ} \mathrm{C}$. During the summer it rains on $>50 \%$ of days and during the winter it rains on an average of $33 \%$ of days. Mean annual rainfall is c. $2,000 \mathrm{~mm}$ (IPARDES, 2001).

\section{Methods}

\section{Study groups and home range}

The two groups studied in Ariri were Fernanda and Bina (Table 1). The results we present for the two insular groups, $\mathrm{A}$ and $\mathrm{B}$, were obtained through meta-analysis of the data obtained by Schmidlin (2004) (Nascimento, 2008; Table 1). Groups were captured and one adult member of each was fitted with a radio collar (Jacob \& Rudran, 2003), allowing us to habituate and follow them. Data for the mainland groups were collected on 3 consecutive days each month, from sleeping site to sleeping site (Nascimento, 2008). The groups on Superagui were followed during 5 complete days each month (Schmidlin, 2004). The locations of the groups were recorded every 20 minutes, including early morning and evening sleeping sites.

We used the kernel method to estimate the home range of the groups with the extension Animal Movement
TABLE 1 Group size of the four Leontopithecus caissara groups on the mainland at Ariri and on the island of Superagui (Fig. 1) and observation period and times.

\begin{tabular}{|c|c|c|c|c|c|}
\hline Group & $\begin{array}{l}\text { Group } \\
\text { size }\end{array}$ & Period & Months & Days & $\begin{array}{l}\text { Total } \\
\text { hours }\end{array}$ \\
\hline \multicolumn{6}{|l|}{ Mainland } \\
\hline Fernanda & $3-4$ & Aug. 2005-Feb. 2007 & 19 & 56 & 504 \\
\hline Bina & $3-5$ & Aug. 2006-Mar. 2007 & 12 & 36 & 324 \\
\hline \multicolumn{6}{|l|}{ Island } \\
\hline A & $4-6$ & June 2000-Oct. 2000 & 5 & 25 & 225 \\
\hline B & $4-7$ & Sep. 2001-July 2002 & 11 & 55 & 495 \\
\hline
\end{tabular}

Analysis (Hooge \& Eichenlaub, 1997) to ArcView v. 3.3 (ESRI, Redlands, USA). The main advantage of kernel estimators is that they combine a probabilistic environment with a non-parametric structure. They are also not affected by the position and shape of the grids used to estimate centres of activity and ranging patterns (Powell, 2000; Jacob \& Rudran, 2003). The kernel estimator uses a group of density probability functions (kernels), associated with all locations sampled (Worton, 1989). The density probability contours of the home range, drawn on a grid, are described and estimated from the desired percentage of the distribution used (Powell, 2000; Jacob \& Rudran, 2003). We used $95 \%$ of the distribution to define the usable home range. A smoothing factor (Worton, 1989; Seaman \& Powell, 1996; Powell, 2000) of 100 was the best fit for L. caissara.

\section{Habitat}

The phytosociological data used are the result of $>8$ years of research throughout the range of L. caissara (Schmidlin, 2004). Data were mapped and analysed using ArcView and the final product was a series of thematic maps of available habitat. Schmidlin (2004) listed 17 vegetation types in the range of L. caissara: 12 on the mainland and 10 on the island. Seven are restricted to the mainland and five to the island, and five occupy both locations (Table 2). More details regarding the habitat classification and geoprocessing method can be found in Schmidlin (2004).

\section{Habitat selection}

We used ArcView to integrate the ranging data and the vegetation maps on the island and mainland, allowing us to quantify the area of each vegetation type within home ranges and to calculate habitat use (the number of records of each group in each vegetation type). The $\chi^{2}$ test was used to compare the proportions of habitat use and availability (Garshelis, 2000; Jacob \& Rudran, 2003). The null hypothesis that habitat use is proportional to its availability was tested for all the habitat types in the home range of each group. A habitat selection index was obtained by dividing 
TABLE 2 Vegetation types available to L. caissara on the mainland and on the island of Superagui (Fig. 1), and used in the analyses of habitat selection.

\begin{tabular}{ll}
\hline Mainland & Island \\
\hline Mangrove $^{\star}$ & Mangrove $^{\star}$ \\
Secondary forest (early succession) & Secondary forest (early succession) \\
Secondary forest (intermediate succession) & Secondary forest (intermediate succession) \\
Submontane forest & Submontane forest \\
Submontane forest $>40 \mathrm{~m}$ above sea level & Seasonally inundated areas (várzea, caxetal) \\
Alluvial forest & Lowland forest \\
Swamp and inundated areas (brejo, várzea, caxetal) & Swamp (brejo) \\
Forest on sandy soil (restinga arbórea) & Forest on sandy soil (restinga arbórea) \\
Hydromorphic lowland forest & Scrub on sandy soil (restinga arbustiva) \\
Non-hydromorphic lowland forest & Herbaceous vegetation on sandy soil (restinga herbácea)
\end{tabular}

Urbanized areas (gardens, fields, villages)

Altered forest

${ }^{\star}$ Schmidlin (2004) identified three separate classes of mangrove. The island groups A and B never entered mangroves and therefore we have pooled the three classes.

the proportion of use by the availability of the respective habitat in the home range. An examination of habitat preference for sleeping sites was possible only for the mainland groups.

\section{Carrying capacity}

We calculated carrying capacity using $K=\left(D_{\text {total }} / A-S\right) \times$ mean group size, and $K^{\star}$ index $=\sum\left[\left(D_{\mathrm{cv}} \times \mathrm{I}_{\mathrm{cv}}\right) /(A-S)\right] \times$ mean group size, where $K$ is the carrying capacity, $D_{\text {total }}$ is the total area available considering all vegetation classes together, $A$ is the area (ha) of the home range, $S$ is home range overlap (ha), $D_{\mathrm{vc}}$ is the total area (ha) of each vegetation class available, and $I_{\mathrm{vc}}$ is the habitat selection index for each vegetation class. $K$ is then multiplied by the mean number of individuals per group to produce an estimate of the number of individuals within a defined area. $\mathrm{K}^{\star}$ index takes into consideration the habitat selection index of the species for each vegetation class. The index predicts core areas of use on the mainland and island and potential areas for conservation outside the species' current range (as proposed by Schmidlin, 2004). The habitat selection index used for this calculation was obtained by taking the means of habitat use of the two studied groups in the Ariri region and Superagui island.

To calculate $A$ we used the mean of the home range size of seven groups: two in Ariri and the five previously studied on Superagui (F. Prado, unpubl. data 1999; Schmidlin, 2004). No information is available for $S$ of the five groups on Superagui and therefore the value used was that for the two groups on the mainland (Nascimento, 2008). The extent of each vegetation type was obtained from the GIS thematic maps produced by Schmidlin (2004). The mean number of individuals per group used was 4.5 (Amaral et al., 2003).

\section{Results}

\section{Habitat selection}

We found no differences in the relation between habitat use and availability for the mainland $L$. caissara groups between the colder (May-October) and warmer (November-April) months (Fernanda group: $t=-1.73, \mathrm{df}=12, \mathrm{P}=0.11$; Bina group: $t=0.86, \mathrm{df}=10, \mathrm{P}=0.41)$. The home range of the mainland groups overlapped with eight vegetation classes. More than half of the estimated home ranges $(55.6 \%$ for the Fernanda group and $69.3 \%$ for the Bina group) included a combination of submontane forest below and above $40 \mathrm{~m}$ (Table 3).

The Fernanda group did not use the vegetation types in its home range according to availability $\left(\chi^{2}=68.84, \mathrm{df}=7\right.$, $\mathrm{P}<0.001$; Table 3). Swamp and inundated areas (brejo, várzea and caxetal) were used more than would be expected considering their extent in the home range. Secondary forest (intermediate succession) and submontane forest were also used more than expected. Submontane forest of $>40 \mathrm{~m}$ altitude was avoided, as were hydromorphic lowland forest and urbanized areas. There was no evidence for any habitat preference by the Fernanda group in its choice of sleeping sites $\left(\chi^{2}=0.70, \mathrm{df}=4, \mathrm{P}=0.93\right)$. The group slept in sites in five of the eight vegetation classes $(89.25 \%)$ in the home range. Even though it spent more time than would be expected in swamp and inundated areas (brejo, várzea and caxetal) during the day, this was not reflected in the choice of sleeping sites.

The Bina group used the vegetation types in its home range in proportion to their availability $\left(\chi^{2}=11.42, \mathrm{df}=7\right.$, $\mathrm{P}=0.15$; Table 3 ). The habitat selection index showed that the swamp and inundated areas and secondary forest were the habitats most intensively used by this group. The group used sleeping sites in six of the eight vegetation classes 
TABle 3 Habitat (Table 2) selection by the four groups of L. caissara (Table 1), showing the area of each habitat available and its use (the number of location points gathered during data collection), with respective percentages, the habitat selection index (\% of use / $\%$ of availability of each vegetation type) ordered by decreasing preference, and $\chi^{2}$ test of the null hypothesis that habitat use is proportional to its availability (positive, negative and equal signs indicate positive, negative and neutral habitat selection, respectively).

\begin{tabular}{|c|c|c|c|c|}
\hline Vegetation types (by L. caissara group) & $\begin{array}{l}\text { Availability, } \\
\text { ha (\%) }\end{array}$ & Use $(\%)$ & $\begin{array}{l}\text { Habitat } \\
\text { selection } \\
\text { index }\end{array}$ & $\chi^{2}$ (selection) \\
\hline \multicolumn{5}{|l|}{ Fernanda group } \\
\hline Swamp and inundated areas (brejo, várzea and caxetal) & $2.00(0.36)$ & $18.00(1.10)$ & 3.07 & $25.12(+)$ \\
\hline Secondary forest (intermediate succession) & $50.00(8.96)$ & $178.00(10.88)$ & 1.21 & $6.73(+)$ \\
\hline Submontane forest & $256.00(45.88)$ & $788.00(48.17)$ & 1.05 & $1.87(+)$ \\
\hline Non-hydromorphic lowland forest & $99.00(17.74)$ & $299.00(18.28)$ & 1.03 & $0.26(=)$ \\
\hline Altered vegetation & $69.00(12.37)$ & $203.00(12.41)$ & 1.00 & $0.00(=)$ \\
\hline Hydromorphic lowland forest & $24.00(4.30)$ & $50.00(3.06)$ & 0.71 & $5.89(-)$ \\
\hline Urbanized areas & $4.00(0.72)$ & $8.00(0.49)$ & 0.68 & $1.18(-)$ \\
\hline Submontane forest $>40 \mathrm{~m}$ elevation & $54.00(9.68)$ & $92.00(5.62)$ & 0.58 & $27.78(-)$ \\
\hline Total & $558.00(100)$ & $1,636.00(100)$ & & 68.84 \\
\hline \multicolumn{5}{|l|}{ Bina group } \\
\hline Hydromorphic lowland forest & $3.00(1.08)$ & $16.00(1.52)$ & 1.40 & $1.82(+)$ \\
\hline Swamp and inundated areas (brejo, várzea and caxetal) & $3.00(1.08)$ & $14.00(1.33)$ & 1.22 & $0.57(+)$ \\
\hline Altered vegetation & $36.00(13.00)$ & $168.00(15.91)$ & 1.22 & $6.89(+)$ \\
\hline Secondary forest (intermediate succession) & $22.00(7.94)$ & $81.00(7.67)$ & 0.97 & $0.10(=)$ \\
\hline Submontane forest & $178.00(64.26)$ & $655.00(62.03)$ & 0.97 & $0.82(-)$ \\
\hline Non-hydromorphic lowland forest & $17.00(6.14)$ & $62.00(5.87)$ & 0.96 & $0.12(=)$ \\
\hline Submontane forest $>40 \mathrm{~m}$ elevation & $14.00(5.05)$ & $47.00(4.45)$ & 0.88 & $0.76(-)$ \\
\hline Urbanized areas & $4.00(1.44)$ & $13.00(1.23)$ & 0.85 & $0.33(-)$ \\
\hline Total & $277.00(100.00)$ & $1,056.00(100.00)$ & & 11.42 \\
\hline \multicolumn{5}{|l|}{ Group A } \\
\hline Lowland forest & $57.10(26.82)$ & $155.00(37.44)$ & 1.40 & $17.41(+)$ \\
\hline Arboreal restinga & $87.70(41.19)$ & $175.00(42.27)$ & 1.03 & $0.12(+)$ \\
\hline Shrub restinga & $42.20(19.82)$ & $79.00(19.08)$ & 0.96 & $0.11(=)$ \\
\hline Seasonally inundated areas (várzeas and caxetais) & $10.70(5.03)$ & $5.00(1.21)$ & 0.24 & $12.01(-)$ \\
\hline Swamp areas (brejo) & $12.50(5.87)$ & 0.00 & 0.00 & $24.31(-)$ \\
\hline Herbaceous restinga & $2.40(1.13)$ & 0.00 & 0.00 & $4.67(-)$ \\
\hline Mangrove & $0.30(0.14)$ & 0.00 & 0.00 & $0.58(=)$ \\
\hline Total & $212.90(100.00)$ & $414.00(100.00)$ & & 59.21 \\
\hline \multicolumn{5}{|l|}{ Group B } \\
\hline Lowland forest & $48.38(29.81)$ & $201.00(34.78)$ & 1.17 & $4.78(+)$ \\
\hline Arboreal restinga & $64.22(39.57)$ & $232.00(40.14)$ & 1.01 & $0.05(+)$ \\
\hline Shrub restinga & $39.61(24.40)$ & $139.00(24.05)$ & 0.99 & $0.03(=)$ \\
\hline Seasonal inundated areas (várzeas and caxetais) & $2.40(1.48)$ & 0.00 & 0.00 & $8.56(-)$ \\
\hline Swamp areas (brejo) & $7.42(4.57)$ & $6.00(1.04)$ & 0.23 & $15.77(-)$ \\
\hline Herbaceous restinga & $0.05(0.03)$ & 0.00 & 0.00 & $0.18(=)$ \\
\hline Mangrove & $0.22(0.13)$ & 0.00 & 0.00 & $0.77(=)$ \\
\hline Total & $162.30(100.00)$ & $578(100)$ & & 30.14 \\
\hline
\end{tabular}

available in its home range $(97.47 \%)$ but used areas of degraded vegetation more than expected and avoided areas of submontane forest $\left(\chi^{2}=21.72, \mathrm{df}=5, \mathrm{P}<0.001\right)$.

On Superagui island groups A and B did not use habitats in proportion to availability in their home ranges (group A: $\chi^{2}=59.21, \mathrm{df}=6, \mathrm{P}<0.001$; group $\mathrm{B}: \chi^{2}=30.14, \mathrm{df}=6$, $\mathrm{P}<0.001)$. Contrary to the pattern observed on the mainland, the vegetation classes used most intensely (lowland forest and arboreal restinga) were also those predominant in the home ranges of these groups (Table 3 ).
Lowland forest and arboreal restinga made up almost $70 \%$ of the home range of group A and both were used more than expected (Table 3). The swamps (brejo), herbaceous restinga and mangroves were not used all. The shrub restinga was used as often as would be expected but the seasonally inundated areas were avoided. Four of the seven vegetation types in the home range were used, corresponding to $92.9 \%$ of the home range.

Group B also used lowland forest and arboreal restinga more than expected (Table 3). Scrub restinga was used in 
proportion to its extent in the home range but seasonally inundated areas and swamps, herbaceous restinga and mangroves were avoided.

\section{Carrying capacity}

Carrying capacity on the mainland and island were estimated to be 277 and 400, respectively; i.e. a total of 677 when not taking into account habitat selection (Table 4). These numbers increase slightly (by 6\%) when the habitat selection index is included in the calculation, to 292 and 422 for the mainland and Superagui, respectively, totalling 714 . Considering areas contiguous with the geographical range on the mainland where L. caissara has not been recorded but which have apparently suitable vegetation types, these values could be doubled, and therefore our estimate of total carrying capacity is 1,386 , or 1,477 taking into account the habitat selection index (Table 4).

The carrying capacities of the vegetation types on the mainland are shown in Table 5. These emphasize the overriding importance for the species of submontane forests of $<40 \mathrm{~m}$ altitude, not only the lowland hydromorphic and non-hydromorphic forests but, as indicated by the habitat use patterns of the two groups at Ariri, also the swamp forest (brejo) and inundated forests (várzea and caxetal). Table 6 shows the carrying capacity for the vegetation types on Superagui. The key vegetation types are arboreal and scrubby restinga and lowland forest. No areas unoccupied by $L$. caissara that could potentially sustain them were identified on the island.

\section{Discussion}

The swamp and inundated areas (brejo, várzea and caxetal) were used intensively by the two mainland groups of $L$. caissara even though these areas comprise a relatively small percentage of the available area. Although it is possible that the selection

TABlE 4 Estimates of the carrying capacity (as both $\mathrm{K}$ and $\mathrm{K}^{\star}$ index; see text for details) for $L$. caissara on the mainland and on Superagui island (Fig. 1), with the total for the two areas, and for the areas of potential, but currently unoccupied, habitat on the mainland, and the total overall for both known and potential ranges.

\begin{tabular}{lccc}
\hline & Area (ha) & K & K$^{*}$ index \\
\hline Mainland & $10,427.9$ & 276.7 & 291.6 \\
$\begin{array}{l}\text { Superagui island } \\
\text { Total (known geographical }\end{array}$ & $13,000.8$ & 399.7 & 421.8 \\
$\quad$ range) & $23,428.8$ & 676.4 & 713.4 \\
$\begin{array}{l}\text { Mainland (areas of potential } \\
\quad \text { habitat) }\end{array}$ & $26,723.0$ & 709.1 & 763.2 \\
$\begin{array}{l}\text { Total (known and potential } \\
\quad \text { range) }\end{array}$ & $50,151.8$ & $1,385.6$ & $1,476.7$ \\
\hline
\end{tabular}

TABLE 5 Estimates of the carrying capacity (as $K^{\star}$ index; see text for details) of each vegetation type for the mainland (Fig. 1) population of L. caissara, for both the known geographical range and for the areas of potential, but currently unoccupied, habitat.

\begin{tabular}{|c|c|c|c|c|}
\hline \multirow[b]{2}{*}{ Vegetation type } & \multicolumn{2}{|c|}{$\begin{array}{l}\text { Known } \\
\text { geographical } \\
\text { range }\end{array}$} & \multicolumn{2}{|c|}{ Potential habitat } \\
\hline & Area (ha) & $K^{\star}$ index & Area (ha) & $K^{\star}$ index \\
\hline Urbanized areas & 32.97 & 0.67 & 248.03 & 5.05 \\
\hline Alluvial forest & 48.28 & 1.28 & 336.72 & 8.94 \\
\hline Submontane forest & $3,390.76$ & 90.66 & $5,963.24$ & 159.44 \\
\hline $\begin{array}{l}\text { Hydromorphic } \\
\text { lowland forest }\end{array}$ & $3,005.19$ & 84.12 & $7,588.81$ & 212.42 \\
\hline $\begin{array}{l}\text { Non-hydromorphic } \\
\text { lowland forest }\end{array}$ & $2,559.35$ & 67.47 & $4,935.65$ & 130.11 \\
\hline $\begin{array}{l}\text { Swamp and inundated } \\
\text { areas (brejo, várzea } \\
\text { and caxetal) }\end{array}$ & 246.00 & 14.01 & 911.00 & 51.90 \\
\hline Arboreal restinga & 38.79 & 1.03 & 144.21 & 3.83 \\
\hline Altered vegetation & 582.31 & 17.21 & $1,388.69$ & 41.04 \\
\hline $\begin{array}{l}\text { Secondary forest } \\
\quad \text { (initial succession) }\end{array}$ & 10.20 & 0.27 & 21.80 & 0.58 \\
\hline $\begin{array}{l}\text { Secondary forest } \\
\text { (intermediate } \\
\text { succession) }\end{array}$ & 514.09 & 14.87 & $5,184.91$ & 149.98 \\
\hline Total & $10,427.92$ & 291.59 & $26,723.08$ & 763.29 \\
\hline
\end{tabular}

of this habitat is fortuitous L. caissara is omnivorous (consuming fruits, insects, small frogs, a species of fungi, and flowers and their nectar) and swampy areas have high densities of microhabitats favoured by insects and a number of tree species that provide fruits and nectar (Coimbra-Filho \& Mittermeier, 1973; Coimbra-Filho, 1981; Rylands, 1989, 1993; Dietz et al., 1997; Oliveira, 2002). Although much used during the day, the swamps and inundated areas were not preferred as sleeping sites (tree hollows, Indaiá palms Attalea dubia or epiphytic bromeliads). The patchy distribution of the plants in these areas, the lack of Indaiá palms and the relative lack of larger trees with hollows for sleeping may

TABLE 6 Estimates of the carrying capacity (as $K^{\star}$ index; see text for details) of each vegetation type for the Superagui island (Fig. 1) population of L. caissara.

\begin{tabular}{lrr}
\hline Vegetation type & Area (ha) & $K^{\star}$ index \\
\hline Submontane forest & 34.42 & 1.06 \\
Lowland forest & $6,727.04$ & 264.98 \\
Seasonal inundated areas & 560.74 & 2.07 \\
$\quad$ várzeas and caxetais) & & \\
Swamp areas (brejo) & 736.04 & 2.57 \\
Arboreal restinga & $1,773.32$ & 55.62 \\
Shrub restinga & $2,363.91$ & 70.79 \\
Herbaceous restinga & 510.23 & 15.69 \\
Secondary forest (initial succession) & 180.85 & 5.56 \\
Secondary forest (intermediate & 114.35 & 3.52 \\
$\quad$ succession) & & \\
Total & $13,000.09$ & 421.86 \\
\hline
\end{tabular}


explain this. In addition, the epiphytic bromeliads tend to be smaller in the swamps and inundated areas than in neighbouring habitats.

The mainland groups also positively selected secondary forest in the intermediate stages of succession in addition to altered vegetation that typically contains numerous elements of secondary successional forest. This preference for altered vegetation contiguous to large areas of mature forest corroborates the adaptability to habitat variations described for other lion tamarin species (Peres, 1986; Rylands, 1989, 1996; Valladares-Padua, 1993, 1997; Rylands et al., 2002). The dense clumps of pioneer trees of secondary and altered vegetation types typically have small and sweet fruits that are abundant and fruit for prolonged periods. In addition, there are higher densities of small animal prey typical of these forests. Those secondary and altered vegetation types were largely absent from the home ranges of the groups studied on the island.

Although lion tamarins are believed to be adapted to tall mature lowland forests with a sparse understorey (Rylands, 1993, 1996), the majority of the lion tamarin populations are now found in areas of secondary forest in various stages of succession. If there is still a Leontopithecus population living in a continuous forest similar to that in which it evolved, this may be the mainland population of L. caissara. In these areas there are still large tracts of coastal lowland forest and forests at higher altitudes, from sea level to the highest ranges of the Serra do Mar. Thus, we have confirmed the preference of $L$. caissara for areas of mature forest, lowlands and slopes at low altitudes, corroborating the patterns originally described for the genus. Their ability to thrive even in secondary forest and highly disturbed forests explains why the species of lion tamarins endemic to the Atlantic forest have been able to survive the degradation, transformation and loss of their habitat.

The avoidance of submontane forest above $40 \mathrm{~m}$ altitude by $L$. caissara and the relative lack of preference for submontane forest (considering the large areas of this vegetation type in the groups' home ranges) explains the restriction of the species to low-elevation areas. Three of the four species of Leontopithecus are restricted to coastal areas at altitudes close to sea level (Peres, 1986; Rylands, 1993, 1996; Rylands et al., 2002). These coastal lowland forests, however, are in large part destroyed, degraded and fragmented; the majority of the remaining Brazilian Atlantic forest is on mountains and hills, distant from the coast (Fundação SOS Mata Atlântica \& INPE, 2002). The black lion tamarin L. chrysopygus is the exception in that it occurs inland in seasonal semi-deciduous forest in the state of São Paulo and was recently recorded at $900 \mathrm{~m}$ in the region of Serra da Paranapiacaba (Röhe et al., 2003).

L. caissara has the smallest geographical range of any of the lion tamarin species, with its main distribution restricted to low altitudes. Lorini \& Persson (1994) recorded that the mainland populations were restricted to altitudes $<50 \mathrm{~m}$, and this is confirmed by our studies in Ariri. This is because of the southerly location of the species' range (the most southerly of any of the New World callitrichids) where changes in temperature and floristic communities with altitude are relatively abrupt (Schmidlin, 2004). One of the reasons the distribution of this species is restricted in our study area is because the Serra do Mar comes close to the coast in northern Paraná and south-east São Paulo. In the ranges of the other lion tamarin species, such as L. rosalia and L. chrysomelas in São Paulo, Rio de Janeiro and Bahia states, submontane forests occur above $100 \mathrm{~m}$ altitude, with altitudinal changes being less dramatic (IBGE, 1992).

The ranging patterns and the vegetation types used by the island groups contrasted with those of the mainland. The two insular groups followed the bands of mangroves parallel to the shoreline, overlapping six of the 11 distinct vegetation types. Only two of these six were used more intensively, containing c. $77 \%$ of all location points: lowland forest and arboreal restinga. The habitat selection index shows the most intensive use of these vegetation types by the island groups.

Lowland forests and arboreal restinga are the most mature vegetation types on Superagui (Schmidlin, 2004), corroborating the description of lion tamarins as typically adapted to low-altitude mature forests (Rylands, 1993, 1996; Valladares-Padua, 1993, 1997; Rylands et al., 2002). In contrast to the mainland groups, these habitats are the most abundant in the home ranges of the insular groups.

L. caissara appears to be unable to thrive in forests at altitudes above $40 \mathrm{~m}$ and this is an important consideration for conservation planning for the species. Incorporation of usable, but unoccupied, preferred habitat outside the current distribution of $L$. caissara indicated that this region could support a doubling of the current carrying capacity for the species. Management should therefore focus on population and habitat viability analysis to identify conservation actions that could increase population size, maintain genetic diversity and decrease pressure on the species and its habitat. Additionally it is important to understand the differences in habitat use and selection between mainland and island populations.

Understanding the reasons for the selection of different habitats by this species is a challenge for future studies and for the design of conservation measures for the species. The need for a better understanding of habitat selection and improved estimates of carrying capacity were identified in the conservation action plan for $L$. caissara (Holst et al., 2006) and have now been provided by our study, the findings of which we have presented to the relevant environmental authorities. The next step will be to carry out a new population and habitat viability analysis to improve the conservation action plan and management programme for the black-faced lion tamarin and its habitat. 


\section{Acknowledgements}

We appreciate the efforts of our field assistants Natanael da Graça, Antônio Carlos Coelho and Luiz S. Constantino. We thank the following institutions and people for their help and support: Parco Zoo Punta Verde, Italy, Whitley Fund for Nature, Margot Marsh Biodiversity Foundation, Idea Wild, Brazilian Environmental Agency (IBAMA/ICMBio), Eliana Reiko Matushima, Claudio Valladares-Padua, Luciano Martins Verdade, Anthony Rylands, Camila Nali and Kaitlin Baird.

\section{References}

Amaral, A.T.N., Prado, F. \& Valladares-Padua, C.B. (2003) Estimativa do tamanho populacional de micos-leões-da-carapreta (Leontopithecus caissara) na ilha de Superagui, Guaraqueçaba, PR, Brasil. In Simpósio Sobre Micos-Leões: Livro de Resumos (eds M.M. de Oliveira, D.M. Rambaldi \& E.C.C. Eloy), p. 64. Centro de Primatas-IBAMA/AMLD, Teresópolis, Brazil.

Coimbra-Filho, A.F. (1981) Animais predados ou rejeitados pelo sauí-piranga, Leontopithecus $r$. rosalia (Leontopithecus, 1766) na sua área de ocorrência primitiva (Callitrichidae, Primates). Revista Brasileira de Biologia, 41, 717-731.

Coimbra-Filho, A.F. \& Mittermeier, R.A. (1973) Distribution and ecology of the genus Leontopithecus Lesson, 1840 in Brazil. Primates, 14, 47-66.

Dietz, J.M., Peres, C.A. \& Pinder, L. (1997) Foraging ecology and use of space in golden lion tamarin (Leontopithecus rosalia). American Journal of Primatology, 41, 282-305.

Fretwell, S.D. \& LuCAS, Jr, H.L. (1970) On territorial behavior and others factors influencing habitat distribution in birds. Acta Biotheoretica, 19, 16-36.

FundaÇÃo SOS Mata Atlântica \& INPE (Instituto Nacional de Pesquisas Espaciais) (2002) Atlas dos Remanescentes Florestais da Mata Atlântica e Ecossistemas Associados no Período de 1995-200o. Relatório Final 1. CD ROM. Fundação SOS Mata Atlântica, INPE, São Paulo, São Jose dos Campos, Brazil.

Garshelis, D.L. (2000) Delusions in habitat evaluation: measuring use, selection, and importance. In Research Techniques in Animal Ecology: Controversies and Consequences (eds L. Boitani \& T.K. Fuller), pp. 111-164. Columbia University Press, New York, USA.

Holst, B., Médici, E.P., Marini-Filho, O.J., Kleiman, D.G., Leus, K., Pissinatti, A. et al. (2006) Lion Tamarin Population and Habitat Viability Assessment Workshop 2005. Final Report. IUCN/Species Survival Commission Conservation Breeding Specialist Group, Apple Valley, USA. Http://www.cbsgeurope.eu/ $\mathrm{cms} /$ showpage.asp? nodeid $=49586$ [accessed 31 January 2008].

Holt, R.D. (1985) Population dynamics in two-patch environments: some anomalous consequences of an optimal habitat distribution. Theoretical Population Biology, 28, 181-208.

Hooge, P.N. \& Eichenla ub, B. (1997) Animal Movement Extension to ArcView, v. 1.1. Alaska Science Center, Biological Science Office, Anchorage, USA.

IBGE (Instituto Brasileiro de Geografia e Estatística) (1992) Manual Técnico da Vegetação Brasileira. Série Manuais Técnicos em Geociências, Instituto Brasileiro de Geografia e Estatística, Rio de Janeiro, Brazil.

ipardes (Instituto Paranaense de Desenvolvimento Econômico e Social) (2001) Zoneamento da APA de Guaraqueçaba. Instituto
Paranaense de Desenvolvimento Econômico e Social. Http:// www.ipardes.gov.br [accessed 25 July 2009].

IUCN (2010) IUCN Red List of Threatened Species v. 2010.4. Http:// www.iucnredlist.org [accessed 22 November 2010].

JAСов, A.A. \& RudRAn, R. (2003) Radiotelemetria em estudos populacionais. In Métodos de Estudos em Biologia da Conservação e Manejo da Vida Silvestre (eds L. Cullen, Jr, R. Rudran \& C.B. Valladares-Padua), pp. 285-342. Editora da Universidade Federal do Paraná, Curitiba, Brazil.

Lorini, M.L. \& Persson, V.G. (1990) Uma nova espécie de Leontopithecus Lesson, 1840, do sul do Brasil (Primattes, Callitrichidae). Boletim do Museu Nacional, 338, 1-14.

Lorini, M.L. \& Persson, V.G. (1994) Status and field research on Leontopithecus caissara: the black-faced lion tamarin project. Neotropical Primates, 2 (suppl.), 52-55.

Matthiopoulos, J. (2003) The use of space by animals as a function of accessibility and preference. Ecological Modeling, 159, $239-268$.

Morris, D.W. (2003) Toward an ecological synthesis: a case for habitat selection. Oecologia, 136, 1-13.

Nascimento, A.T.A. (2008) Uso do espaço e seleção de hábitat pelo Mico-Leão-da-Cara-Preta (Leontopithecus caissara). MSc thesis. São Paulo University, São Paulo, Brazil.

Oliveira, P.P. (2002) Ecologia alimentar, dieta e área de uso de micos-leões-dourados translocados e sua relação com a distribuição espacial e temporal de recursos alimentares na Reserva Biológica União, RJ. PhD thesis. Universidade Federal de Minas Gerais, Belo Horizonte, Brazil.

Peres, C.A. (1986) Golden lion tamarin project II: ranging patterns and habitat selection in golden lion tamarins Leontopithecus rosalia Linnaeus, 1766 (Callitrichidae, Primates). In A Primatologia no Brasil-2 (ed. M.T. de Mello), pp. 223-233. Sociedade Brasileira de Primatologia, Brasília, Brazil.

Powell, R.A. (2000) Animal home range and territories and home range estimators. In Research Techniques in Animal Ecology: Controversies and Consequences (eds L. Boitani \& T.K. Fuller), pp. 65-110. Columbia University Press, New York, USA.

Prado, F. (1999) Ecologia, comportamento e conservação do micoleão-da-cara-preta (Leontopithecus caissara) no Parque Nacional do Superagui, Guaraqueçaba, Paraná. MSc thesis. Universidade Estadual Paulista "Julio de Mesquita Filho", Botucatu, Brazil.

Prado, F., Valladares-Padua, C.B. \& Amaral, A.T.N. (2003) Levantamento populacional de mico-leão-de-cara-preta (Leontopithecus caissara) no Estado de São Paulo, Brasil. In Simpósio Sobre Micos-Leões 3 (eds M.M. de Oliveira, D.M. Rambaldi \& E.C.C. Eloy), p. 65. Centro de Primatas-IBAMA/AMLD, Teresópolis, Brazil.

Pulliam, H.R. (1988) Sources, sinks, and population regulation. American Naturalist, 132, 652-661.

Rhodes, J.R., McAlpine, C.A., Lunney, D. \& Possingham, H.P. (2005) A spatially explicit habitat selection model incorporating home range behavior. Ecology, 86, 1199-1205.

Röhe, F., Antunes, A.P. \& De Tófoli, C.F. (2003) The discovery of a new population of black lion tamarins (Leontopithecus chrysopygus) in the Serra de Paranapiacaba, São Paulo, Brazil. Neotropical Primates, 11, 75-76.

RYLANDS, A.B. (1989) Sympatric Brazilian callitrichids: the blacktufted-ear marmoset, Callithrix kuhli, and the golden-headed lion tamarin, Leontopithecus chrysomelas. Journal of Human Evolution, 18, 679-695.

Rylands, A.B. (1993) The ecology of the lion tamarin, Leontopithecus: some intra-generic differences and comparisons with other callitrichids. In Marmosets and Tamarins: Systematics, Behaviour, and Ecology (ed. A.B. Rylands), pp. 296-313. Oxford University Press, Oxford, UK. 
RYLANDS, A.B. (1996) Habitat and the evolution of social and reproductive behavior in Callitrichidae. American Journal of Primatology, 38, 5-18.

Rylands, A.B., Kierulff, M.C.M. \& Pinto, L.P. de S. (2002) Distribution and status of lion tamarins. In Lion Tamarins: Biology and Conservation (eds D.G. Kleiman \& A.B. Rylands), pp. 42-70. Smithsonian Institution Press, Washington, DC, USA.

Schmidlin, L.A.J. (2004) Análise da disponibilidade de habitat para o mico-leão-da-cara-preta (Leontopithecus caissara Lorini \& Persson, 1990) e identificação de áreas preferenciais para o manejo da espécie por técnicas de geoprocessamento. MSc thesis, Universidade Federal do Paraná, Curitiba, Brazil.

Seaman, D.E. \& Powell, R.A. (1996) An evaluation of the accuracy of kernel density for animal home range analysis. Ecology, 77, 2075-2085.

Valladares-Padua, C.B. (1993) The ecology, behavior and conservation of the black lion tamarins (Leontopithecus chrysopygus, Mikan, 1823). PhD thesis. University of Florida, Gainesville, USA.

Valladares-Padua, C.B. (1997) Habitat analysis for the metapopulation conservation of black lion tamarins (Leontopithecus chrysopygus, Mikan, 1823). In A Primatologia no Brasil-6 (eds M.B.C. Souza \& A.A.L. Menezes), pp. 13-26. Editora da Universidade Federal do Rio Grande do Norte, Sociedade Brasileira de Primatologia, Natal, Brazil.
Valladares-Padua, C.B., Martins, C.S. \& Rudran, R. (2003) Manejo integrado de espécies ameaçadas. In Métodos de Estudos em Biologia da Conservação e Manejo da Vida Silvestre (eds L. Cullen, Jr, R. Rudran \& C.B. Valladares-Padua), pp. 647-665. Editora da Universidade Federal do Paraná, Curitiba, Brazil.

Vive kananda, G. (2001) Parque Nacional do Superagui: a presença humana e os objetivos de conservação. MSc thesis. Universidade Federal do Paraná, Curitiba, Brazil.

Worton, B.J. (1989) Kernel methods for estimating the utilization distribution in home range studies. Ecology, 70, 164-168.

\section{Biographical sketches}

Alexandre T. Amaral Nascimento is interested in the multidisciplinary studies required for long-term species conservation, in applied ecology, and in innovative strategies to link biodiversity conservation and sustainable development. He has been involved with conservation of the black-faced lion tamarin since 2002. LUCIA A. J. SCHMidin died in May 2008. Her expertise in GIS and forestry sciences made a huge difference to the information available on the black-faced lion tamarin. She had only 28 years of life but her achievements reached far beyond. 